\section{A STATISTICAL APPROACH FOR OPTIMIZING THE HIGH YIELD GREEN PRODUCTION OF THE FLAVOR ESTER BUTYL BUTYRATE}

Ida Nurhazwani Abd Rahmana, Fatin Myra Abd Manana, Nur Haziqah Che Marzukia, Naji A. Mahata, Nursyafreena Attana, Aemi Syazwani Abdul Keyona, Joazaizulfazli Jamalisa, Hassan Y. Aboul-Enein ${ }^{b}$, Roswanira Abdul Wahaba*

aDepartment of Chemistry, Faculty of Science, Universiti Teknologi Malaysia, 81310 UTM Johor Bahru, Johor, Malaysia bPharmaceutical and Medicinal Chemistry Department, Pharmaceutical and Drug Industries Research Division, National Research Centre, Dokki, Giza 12622, Egypt
Article history

Received

14 December 2016

Received in revised form

19 June 2017

Accepted

7 August 2017

*Corresponding author roswanira@kimia.fs.utm.my
Graphical abstract

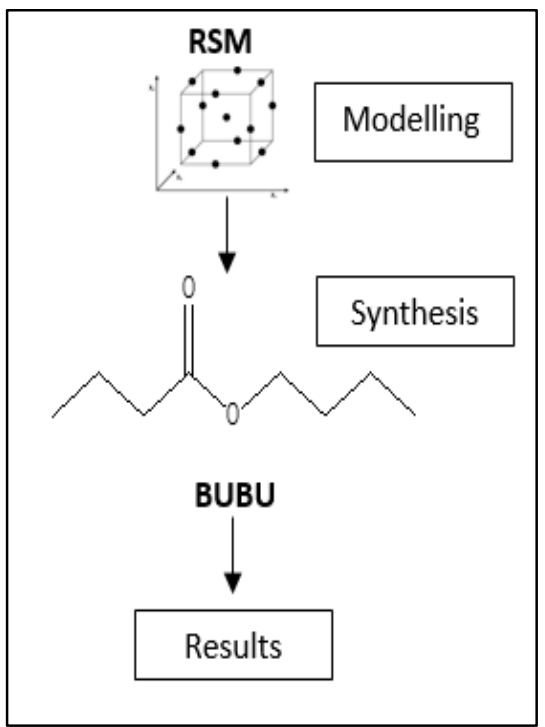

\begin{abstract}
Being the prevailing approach for producing esters such as butyl butyrate, the use of chemical route has been linked to numerous disadvantages. Hence, a green alternative method for higher yield production of butyl butyrate by esterification reaction utilizing Novozyme 435 as biocatalysts in a solvent-less system may prove useful. Such approach can be further improved by optimizing the relevant reaction parameters using the Response Surface Methodology by the Box-Benkhen Design attempted in this present study. The reaction parameters evaluated were: substrate molar ratio, time and temperature, and the response of each parameter was measured as percentage conversion yield. Using the Design Expert 7.1.6 optimization functions, the two sets of optimum conditions selected viz. [i] molar ratio butyric acid:butanol $1: 3.93,9.93 \mathrm{~h}$ at $56.09^{\circ} \mathrm{C}$ and [ii] molar ratio butyric acid:butanol $1: 3.35,9.79 \mathrm{~h}$ at $53.90^{\circ} \mathrm{C}$ had afforded the highest yield of butyl butyrate i.e. $99.62 \%$ and $99.55 \%$, respectively. The ester product obtained from the reaction were confirmed as butyl butyrate by FTIR and GC. Therefore, the results substantiated the applicability of the RSM prediction technique as well as efficacy of Novozyme 435 as biocatalysts in the high yield solvent-less synthesis of butyl butyrate, adhering to the philosophy of Green Chemistry.
\end{abstract}

Keywords: Esterification, butyl butyrate, response surface methodology, BoxBehnken design

\begin{abstract}
Sebagai pendekatan yang lazim untuk menghasilkan ester seperti butil butirat penggunaan laluan kimia telah dikaitkan dengan banyak kelemahan. Oleh itu, kaedah alternatif hijau untuk penghasilan butil butirat yang lebih tinggi dengan tindak balas pengesteran menggunakan Novozyme 435 sebagai mangkin bio dalam sistem tidak berpelarut mungkin berguna. Pendekatan sedemikian dapat ditingkatkan dengan mengoptimumkan parameter tindak balas yang berkaitan dengan menggunakan Kaedah Tindak balas Permukaan melalui Rekabentuk BoxBenkhen yang cuba dalam kajian ini. Parameter tindak balas yang dinilai adalah: nisbah molar substrat, masa dan suhu, dan tindak balas setiap parameter diukur sebagai peratus hasil penukaran. Menggunakan Pakar Reka Bentuk 7.1.6 fungsi pengoptimuman, kedua-dua set keadaan optimum dipilih. [i] nisbah molar asid butirik:butanol 1: $3.93,9.93 \mathrm{~h}$ pada $56.09^{\circ} \mathrm{C}$ dan [ii] nisbah molar asid butirik:butanol
\end{abstract}


1: $3.35,9.79 \mathrm{~h}$ pada $53.90^{\circ} \mathrm{C}$ memberikan hasil tertinggi butil butirat iaitu masingmasing $99.62 \%$ dan $99.55 \%$. Produk ester yang diperolehi daripada tindak balas telah disahkan sebagai butil butirat oleh FTIR dan GC. Oleh itu, hasilnya membuktikan kebolehgunaan teknik ramalan RSM serta keberkesanan Novozyme 435 sebagai mangkin bio dalam sintesis butyl butirat tidak berpelarut, berpegang teguh kepada falsafah Kimia Hijau.

Kata kunci: Pengesteran, butil butirat, kaedah permukaan tindak balas, reka bentuk Box- Behnken

\subsection{INTRODUCTION}

The esters of butyric acid are useful especially in food industries for producing favorable flavors among consumers such as pineapple, mango and banana. At present, the butyrate esters namely propyl butyrate and butyl butyrate are produced via chemically mediated esterification reaction; preferred by manufacturers due to its constant yield of production as compared to extraction from natural resources [1]. Conventionally, the chemical route for producing butyl esters has been associated with numerous environmentally unfavorable practices viz. the use of corrosive acids as catalysts as well as liberation of superfluous harmful unwanted byproducts [1-3]. Moreover, the technique also incurs high energy consumption [2, 4] and tedious downstream separation processes [3]. Furthermore, difficulties in obtaining high yield of the pure butyl butyrate in the commercial Fisher-Speier esterification have been indicated [1], hence limiting the efficacy of such process in the mass production of the ester. This is due to the fact that the elevated temperature $\left[250^{\circ} \mathrm{C}\right]$ in the reaction would lead to counterproductive degradation of the produced ester. Moreover, the homogeneity of the acid catalysts utilized in such reaction would contribute to the unwanted increase in the downstream product purification process [1]. Considering all the limitations in the current Fisher-Speier esterification [1], the pursuit for sustainable and environmentally friendly alternative methods for producing considerably high yield of butyl butyrate merits consideration.

The employment of Green Chemistry philosophy for industrial productions has triggered new challenges for complying with the standard set forth by the European Parliament [i.e. Registration, Evaluation, Authorization and Restriction of Chemicals, REACh] as well as the regulation and environmental restrictions enacted by various countries including the United States, Japan and the European Union [2]. Echoing to such philosophy, initiatives for acquiring "clean and green technologies" have since taken place worldwide [5]. In an effort to offer suitable alternatives to commercial manufacturers for producing such an important ester i.e. butyl butyrate, the biosynthetic route has been widely suggested. In this context, utilization of lipases [triacylglycerol ester hydrolases EC 3.1.1.3] as the biocatalysts for producing butyl butyrate may prove useful [5]. The study believes lipases are the enzyme of choice to catalyze the synthesis of this ester since such enzymes are capable of catalyzing esterification reactions, yielding considerable amount of target products even at ambient conditions $[4,6,7]$. A matter of fact, its application has been acquiring rapid popularity among industrial players [4, 7]. The biotechnological route [e.g. lipases] offers many benefits such as high enzyme activities in water and organic solvents as well conversion of a broad number of substrates with high stereospecificity; in the attempt for producing commercially important esters $[7,8]$. These catalytic characteristics of lipases are highly desirable under industrial settings, especially when it could prospectively lower the production costs as well as improving the yield of butyl butyrate as compared to the current commercial Fisher-Speier process produces low yields (50\%) of the butyl butyrate and incurs high energy demand on the manufacturing process $\left(250^{\circ} \mathrm{C}\right)$ [1]. Hence, the use of lipases for improving the current manufacturing process could circumvent this problem and, most importantly, the use of lipases is also more eco-friendly.

Enzyme stability is an important issue due to its wide range of applications in a diverse field of the industries, especially in terms of application and technology. Enzyme engineering, through immobilization techniques viz. adsorption, multipoint, and multi subunit covalent binding, as well as entrapment, are preferred for enhancing enzyme properties, such as, stability, specificity, activity, and inhibition by reaction products [9]. For ensuring its robustness and cost-effectiveness for industrial applications, immobilization of lipases has become a commonplace technique among biotechnologists [4]. This is because such technique renders a great deal of important benefits viz. improvement of its activity and stability, reusability, easy recovery $[7,10,11]$, robust structural stability, specificity and selectivity as well as reduced inhibition [2]. Considering such multifaceted benefits, the use of commercially developed enzymes such as Novozyme 435 and Lipozyme to produce various commercial esters has been favored by industrial manufacturers [7]. In this regard, a solvent-less biosynthetic reaction is an attractive option, taking into consideration its minimal impact on the environment since the use of flammable organic and toxic solvents can be avoided [12]. In addition, the fact that it promotes sufficient homogeneity for the reaction system, the use of solventless system becomes a fascinating medium for maintaining the effectiveness of an interface acting enzymes such as lipases [12]. 
Marzuki et al. [2015b] remarked that the optimization of esterification parameters being pivotal for economical manufacturing [13]. Being "a collection of statistical and mathematical techniques that optimize responses" [14] and since this technique "is useful for developing, improving and optimizing processes" [15]; utilization of response surface methodology [RSM] for producing butyl butyrate using Novozyme 435 in a solvent-less system is justifiably supported. The general reaction for the Novozyme 435 catalyzed esterification synthesis of butyl butyrate is shown in Scheme 1.

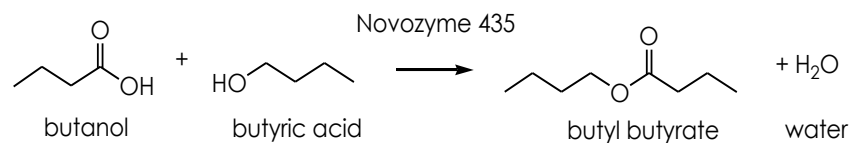

Scheme 1 The general reaction scheme for the Novozyme 435 assisted solvent-free esterification of butyl butyrate.

Considering such advantages, previous studies [12, 13, $16,17]$ pertaining to the synthesis of various esters have successfully utilized RSM, prescribing the optimum conditions for such reactions. In this context, it is pertinent to mention here that the optimized conditions for enhancing the ability of Novozyme 435 in catalyzing high yield solvent-less production of butyl butyrate has not been reported in literature, so far. Therefore, this present study that aimed at establishing the optimized conditions for the maximum yield of butyl butyrate via a solvent-less system viz. time, temperature, molar ratio of substrates and enzyme loading deserves special consideration.

\subsection{METHODOLOGY}

\subsection{Materials}

Butanol [99.4\%], butyric acid [99.0\%], sodium hydroxide pellets, phenolphthalein and Novozyme 435, a recombinant lipase from Candida antarctica $[\geq 5,000$ $\mathrm{U} / \mathrm{g}$ ] expressed in Aspergillus niger and immobilized on acrylic resin was purchased from Sigma-Aldrich [St, Louis, USA]. All other chemicals were of analytical grade and used without further purification. Distilled water was prepared in our laboratory.

\subsection{Esterification for the Synthesis of Butyl Butyrate}

The solvent-less production of butyl butyrate was carried out in a $100 \mathrm{~mL}$ round bottom flask that contained butanol (1.5 M) and butyric acid [0.5 M]. The reaction was initiated by the addition of Novozyme 435 biocatalysts into the reaction mixture. The esterification ratio acid to alcohol (1:1-1:5), time [2-10 h) and reaction was stirred under variable conditions viz. molar temperature $\left(35-65{ }^{\circ} \mathrm{C}\right)$ (Table 1). At designated intervals, samples $(0.2 \mathrm{~mL}$ ) are withdrawn and titrated with $\mathrm{NaOH}(0.05 \mathrm{M})$ using phenolphthalein as indicator.
Table 1 Process variables and their levels used in the BoxBehnken design

\begin{tabular}{|c|c|c|c|c|}
\hline \multicolumn{2}{|c|}{ Variables } & \multicolumn{3}{|c|}{ Ranges and levels } \\
\hline & & -1 & 0 & +1 \\
\hline A & $\begin{array}{l}\text { Molar ratio } \\
\text { [alcohol/acid] }\end{array}$ & 1 & 3 & 5 \\
\hline B & Time $[\mathrm{h}]$ & 2 & 6 & 10 \\
\hline C & Temperature $\left[{ }^{\circ} \mathrm{C}\right]$ & 35 & 50 & 65 \\
\hline
\end{tabular}

\subsection{Determination of Conversion Yield of Butyl Butyrate}

The reaction mixture $(1 \mathrm{~mL})$ was withdrawn every hour for $12 \mathrm{~h}$. Each sample was dissolved in $2 \mathrm{~mL}$ of $\mathrm{n}$-hexane as quenching agent and titrated with $\mathrm{NaOH}(0.05 \mathrm{M})$ using phenolphthalein as indicator. The conversion yield of butyl butyrate was calculated as shown in Eqn. 1:

Conversion $(\%)=\frac{V_{0}-V_{t}}{V_{0}} \times 100$

where: $\mathrm{V}_{0}$ : Volume of $\mathrm{NaOH}$ at initial time $[\dagger=0], \mathrm{V}_{\dagger}$ : Volume of $\mathrm{NaOH}$ at each hour $[t=\uparrow 1,+2,+3 \ldots]$

\subsection{Experimental Design and Statistical Analysis}

A three-factor, three-level Box-Behnken design [BBD] that required 17 experiments was used in this study to evaluate the parameters (Table 1). The logic range for the parameters used in the BBD was ascertained by referring to a previous study by Martins and co-workers [16]. A software package by Design Expert Version 7.1.6 [State-Ease Inc., Statistics Made Easy, Minneapolis, MN, USA] was used to fit this model to the independent variables using model equation to predict the optimum values and subsequently elucidate the interaction between the variables. The quadratic polynomial equation model for predicting the optimal point was expressed according to Eqn. 2:

$y=b_{0}+\sum_{i=1}^{k} b_{i} x_{i}+\sum_{i=1}^{k} b_{i i} x_{i}+\sum_{i}^{i<j} \sum_{j} b_{i j} x_{i} x_{j}$

where $y$ is the response variable to be modeled; $x_{i}$, and $x_{j}$ the independent variables which influence the reaction, $y ; b, b_{i}, b_{i i}$ and $b_{i i}$ are the offset terms, the ith linear coefficient, the quadratic coefficient and the ijth interaction coefficient, respectively. The coefficient of determination $\left[\mathrm{R}^{2}\right]$ could be used to evaluate the accuracy and general ability of the second order multiple regression models. The fitted polynomial equation was expressed as response surface and contour plots for visualizing the relationship between the response and experimental levels of each factor and to deduce the optimum conditions.

\subsection{Analysis of Butyl Butyrate}

In the enzymatic production of butyl butyrate using Novozyme 435, the following analyses were done to confirm the formation of butyl butyrate. Two instruments were used to monitor the production of the ester namely as Fourier Transform Infrared Spectroscopy: 
Attenuated Total Reflectance [FTIR-ATR] and Gas Chromatography [GC].

\subsubsection{FTIR Spectroscopy: Attenuated Total Reflectance [ATR]}

The quantification of butyl butyrate was performed by FTIR-ATR analysis. Spectra from samples were collected in the one-bounce ATR mode in a Spectrum 100 FTIR spectrometer [Perkin-Elmer Inc., Norwalk, CT, USA]. Samples were placed on Diamond/ZnSe crystal plate [Perkin-Elmer] and scanned from 4000 to $650 \mathrm{~cm}-1$ at room temperature. Each sample was replicated three times and the identical spectra were obtained in each case. This process was done to see the accuracy of the absorbance values, which might be affected from intra-sample variability and from variation in experimental conditions. Two samples of reagents with molar ratio of 1:3 [acid:alcohol] were analyzed using this technique. The first sample consisted a of mixture butanol and butyric acid alone while the second one was of butanol and butyric acid with presence of Novozyme 435 after 10 h of reaction.

\subsubsection{Gas Chromatography}

The concentrations of butyl butyrate were determined by GC [Perkin-Elmer Autosystem XL, USA] using FID as the detector. A capillary DB-1 column [J and W, USA], $60 \mathrm{~m} \times 0.32 \mathrm{~mm}$ ID, with a stationary layer thickness of $0.25 \mathrm{~mm}$ of dimethylpolysiloxane was used as the resolution medium. A sample of $1.0 \mu \mathrm{L}$ was injected at $45^{\circ} \mathrm{C}$ and held for $1 \mathrm{~min}$ and the temperature of the column was ramped to $175^{\circ} \mathrm{C}\left[10^{\circ} \mathrm{C} / \mathrm{min}\right]$ and the final temperature was held for $10 \mathrm{~min}$. The temperature of both the injector and detector was maintained at $250^{\circ} \mathrm{C}$, while helium was used as the carrier gas.

\subsection{RESULTS AND DISCUSSION}

3.1 Optimizing the Enzymatic Synthesis of Butyl Butyrate using Response Surface Methodology by Box-Behnken Design: RSM Experiments and Model Fitting

It has been indicated that studying the combined effects of various parameters by conventional methods can potentially be time consuming since such approaches require high number of experiments resulting in wastage of resources [18]. Hence, employment of statistical tools such as response surface methodology [RSM] is particularly beneficial as the method relatively simplifies the reaction parameters needed to establish the optimum conditions of a particular reaction [17-19]. Among the most common design is the Box-Behnken Design [BBD], an efficient design in response surface modelling and presents a convenient choice that necessitates considerably fewer experimental points [three levels per variable] for its application and high efficiency $[20,21]$. Moreover, the RSM optimization to synthesize butyl butyrate in a humid country as Malaysia may prove feasible as there are numerous reports on relatively high yield ester productions [2-6], despite the high humidity of the surrounding environment.

As seen from Table 2, the predicted values obtained with a model fitting technique using RSM were found to sufficiently correlate with the observed values. The best fitting model was established by a regression analysis. Fitting of the data to various models [linear, two factorial, quadratic and cubic] and their following analysis of variance [ANOVA], the esterification of butanol and butyric acid catalyzed by Novozyme 435 in producing butyl butyrate was appropriately described with a quadratic polynomial [Eqn. 3].

Conversion $=79.04+5.55 \mathrm{~A}+25.50 \mathrm{~B}+2.30 \mathrm{C}+0.75 \mathrm{AB}+$ $2.15 A C+3.25 B C-11.70 A^{2}-5.60 B^{2}-12.69 C^{2}$

Table 2 Experimental and results of the Box-Behnken design

\begin{tabular}{|c|c|c|c|c|c|}
\hline Run & $\begin{array}{c}\text { Substrate } \\
\text { molar } \\
\text { ratio }\end{array}$ & $\begin{array}{l}\text { Time } \\
\text { [h] }\end{array}$ & $\begin{array}{c}\text { Temperature } \\
{\left[{ }^{\circ} \mathrm{C}\right]}\end{array}$ & $\begin{array}{c}\text { Actual } \\
\text { conversion } \\
\%\end{array}$ & $\begin{array}{c}\text { Predicted } \\
\text { conversion } \\
\%\end{array}$ \\
\hline 1 & 3 & 6 & 50 & 79.5 & 79.04 \\
\hline 2 & 3 & 2 & 35 & 38.0 & 36.20 \\
\hline 3 & 3 & 6 & 50 & 79.5 & 79.04 \\
\hline 4 & 5 & 6 & 35 & 55.0 & 55.75 \\
\hline 5 & 1 & 6 & 35 & 48.6 & 48.95 \\
\hline 6 & 1 & 2 & 50 & 30.0 & 31.45 \\
\hline 7 & 3 & 6 & 50 & 80.0 & 79.04 \\
\hline 8 & 1 & 10 & 50 & 82.0 & 80.95 \\
\hline 9 & 3 & 10 & 35 & 80.0 & 80.70 \\
\hline 10 & 5 & 10 & 50 & 95.0 & 93.55 \\
\hline 11 & 5 & 2 & 50 & 40.0 & 41.05 \\
\hline 12 & 3 & 10 & 65 & 90.0 & 91.80 \\
\hline 13 & 5 & 6 & 65 & 65.0 & 64.65 \\
\hline 14 & 3 & 6 & 50 & 78.1 & 79.04 \\
\hline 15 & 3 & 6 & 50 & 78.1 & 79.04 \\
\hline 16 & 3 & 2 & 65 & 35.0 & 34.30 \\
\hline 17 & 1 & 6 & 65 & 50.0 & 49.25 \\
\hline
\end{tabular}

The terms A, B and C represent substrate molar ratio, time and temperature of the reactions, respectively. From Eqn. 3, it can be seen that each term that corresponded to a mutual interaction between variables carried a positive sign. The corresponding signs [+/-] prefixing each term describe the influence of independent variables on the Novozyme 435 catalyzed esterification reaction. The positive sign [+] implies the synergistic effect, while the negative sign [-] illustrated the antagonistic effect between the interacting variables. In this study, it was evident that mutual interactions between all the variables were synergistic. Pertinently, a very small $P$-value $[<0.0001]$ would indicate the significance of the corresponding coefficient [22]. In contrast, the larger F-value is, the more significant the corresponding coefficient would be [23]. It was evident that the reaction time being the key variable that afforded the highest impact on the 
esterification reaction.

The results of $\mathrm{BBD}$ revealed that the conditions described in run \#10 [50 $\mathrm{C}, 1: 5$ [butyric acid:butanol], $10 \mathrm{~h}$ enzyme content $5 \mathrm{mg} / \mathrm{mL}$ by substrate volume] yielded the highest actual conversion of butyl butyrate [95.0\%], while the lowest actual conversion of $30 \%$ prevailed when the reaction was tested against the conditions described in run \#6 $\left[50^{\circ} \mathrm{C}, 1: 5\right.$ [butyric acid:butanol], $2 \mathrm{~h}$, enzyme content $5 \mathrm{mg} / \mathrm{mL}$ ] [Table 2]. In general, most of the experimental runs afforded about $70 \%$ conversions of butyl butyrate within the stipulated reaction time. The results strongly suggested that the Novozyme 435 had good activity and efficacy in catalyzing such high yield production of the ester.

Statistical testing of the model was done using the Fisher's statistical test for ANOVA and the results were tabulated in Table 3. It is paramount to highlight that the $P$-value [< 0.05] would indicate the significance of a model. Since the computed F-value of the model [300.15] was considerably higher than that of the tabular $F_{0.05}[9,7]=3.68$, it can be construed that the degree of freedom relative to residual obtained for the model was significant at the $5 \%$ confidence level. The obtained small $P$-value $[<0.0001]$ along with a coefficient of determination of nearly 1 [24] $\left[R^{2}=0.9974\right]$ would suggest that the model obtained was highly significant, implying that the quadratic polynomial model was sufficient to explain the actual relationship between the response and the variables. The obtained $\mathrm{R}^{2}$ suggests that there was a total variation that consisted of more than $99 \%$ for the acid conversion to the independent variables.

Except for temperature, the ANOVA [Table 3] revealed that other independent variables [A: molar ratio, $B$ : time] were statistically significant [ $P$-values $<0.0001]$ for the Novozyme 435 catalyzed esterification of butanol and butyric acid to produce butyl butyrate. All terms that represented the mutual interaction between variables were found to be significant [AC: molar ratio $x$ temperature; $\mathrm{BC}$ : time $\mathrm{x}$ temperature] with an exception of $A B$ [molar ratio $x$ time]. However, the insignificant term was retained in order to preserve the required hierarchy of the model.

Table 3 Analysis of variance and model coefficients for the Novozyme 435 assisted solvent-free esterification of butyl butyrate

\begin{tabular}{llcllll}
\hline Source & Sum of squares & $\begin{array}{c}\text { Degree } \\
\text { of } \\
\text { freedom }\end{array}$ & $\begin{array}{c}\text { Mean } \\
\text { square }\end{array}$ & F-value & $\boldsymbol{P}$-value & significant \\
\hline Model & 7082.24 & 9 & 786.92 & 300.15 & $<0.0001$ & $<0.0001$ \\
A-molar ratio & 246.42 & 1 & 246.42 & 93.99 & $<0.0001$ & 0.0051 \\
B-time & 5202 & 1 & 5202 & 1984.2 & 0.3851 & 0.0327 \\
C-temperature & 42.32 & 1 & 42.32 & 16.14 & 0.0051 \\
$\mathrm{AB}$ & 2.25 & 1 & 2.25 & 0.86 & $<0.0001$ \\
$\mathrm{AC}$ & 18.49 & 1 & 18.49 & 7.05 & 0.0002 \\
$\mathrm{BC}$ & 42.25 & 1 & 42.25 & 16.12 & $<0.0001$ \\
$\mathrm{~A}_{2}$ & 575.89 & 1 & 575.89 & 219.66 & \\
$\mathrm{~B} 2$ & 131.81 & 1 & 131.81 & 50.27 & not significant \\
$\mathrm{C}_{2}$ & 678.58 & 1 & 678.58 & 258.83 & \\
Residual & 18.35 & 7 & 2.62 & & \\
Lack of Fit & 15.24 & 3 & 5.08 & 6.53 & \\
Pure Error & 3.11 & 4 & 0.78 & & \\
Cor Total & 7100.6 & 16 & & & \\
\hline
\end{tabular}

Comparisons between the predicted and actual yields of butyl butyrate revealed that the values of the actual and predicted yields correlated well and were similar $\left[R^{2}=0.9974\right]$. Considering that the adjusted $R^{2}$ value [0.9941] was closely similar to the $R^{2}$ value, the use of quadratic polynomial model generated in explaining the actual relationship between the response and the variables may prove satisfactory. The high value of adequate precision [50.006] strongly indicated that the signal to noise ratio obtained for this model was acceptable. According to the ANOVA factors [Table 3] the F-value for the lack of fit was 6.53, lower than the tabulated value of $\mathrm{F}_{0.05}[3,4]=6.59$, indicating the lack of fit was insignificant relative to pure error. Such finding further proves that the data in the experimental domain were well represented by the model [25]. The lack of fit measures the failure of the model to represent the data in the experimental domain at points which are not included in the regression [25]. In this study, the insignificance of the lack of fit signifies that the model equation used was sufficient for predicting the conversion of butyl butyrate under any combination of values of the variables.

\subsection{Effect of Process Variables on the Percentage Yield of Butyl Butyrate}

Figure 1 illustrates the deviation of the reference point for the percentage conversion of butyl butyrate for the effects of molar ratio $[A]$, time $[B]$ and temperature $[C]$. The percentage yield of butyl butyrate increased steadily with the increment of substrate molar ratio acid 
to alcohol. However, the conversion showed a slight decline when the molar ratio of butanol:butyric acid approached 1:4. Lower conversion of butyl butyrate was observed at molar ratio of 1:1 and conversely, the highest conversion was attained when the molar ratio was increased to 1:3. The outcome shows that the Novozyme 435 catalyzed esterification of butanol with butyric acid was more favorable at higher alcohol to acid molar ratio, consistent with the finding reported by the previous researchers [26].

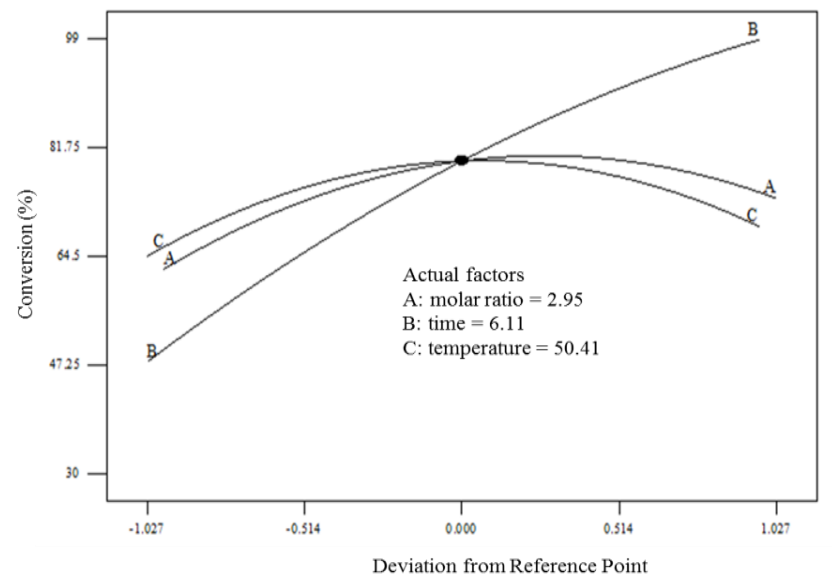

Figure 1 The deviation from the reference point for the percentage conversion of butyl butyrate for the effects of $A$ ) molar ratio, B) time and C) temperature

Contrasting to the effect of $A$, the percentage yield of butyl butyrate had increased drastically with longer $\mathrm{B}$, attaining the highest yield of the ester at $10 \mathrm{~h}$. The rather steep ascending trend demonstrated by $B$ corroborated with its very large F-value [1984.2] when compared with that of $A$ [93.99] and C [16.14], confirming that time being the most important variable in the esterification reaction. A steady upward trend of percentage conversion of ester with the increase of the reaction $\mathrm{C}$ was observed, in consistency with the find of the previous researchers [27]. According to Figure 1, the optimum temperature for this case was approximately $50^{\circ} \mathrm{C}$, beyond which the percentage conversion of butyl butyrate started to decline.

\subsection{Interactive Effects of Factors on the Novozyme 435 Catalyzed Esterification of Butanol and Butyric Acid}

\subsubsection{Effect of Molar Ratio and Temperature}

The three-dimensional surface plots are generated to show the effect of the independent variables on the dependent ones, while the contour plots can clearly indicate the percentage conversions of the reaction. The maximum predicted values are represented by the surface confined in the smallest ellipse in the contour diagram [28]. Figure 2 illustrates the effect of varying molar ratio of butanol:butyric acid and temperature on the Novozyme 435 catalyzed production of butyl butyrate at constant time of $6 \mathrm{~h}$. Moreover, the effect molar ratio [F-value 93.99] on the yield of butyl butyrate was more impacting than the substrate temperature [Fvalue 16.14] in this enzymatic catalysis. The interactions between the two variables were significant because of the small $P$-value [0.0327].
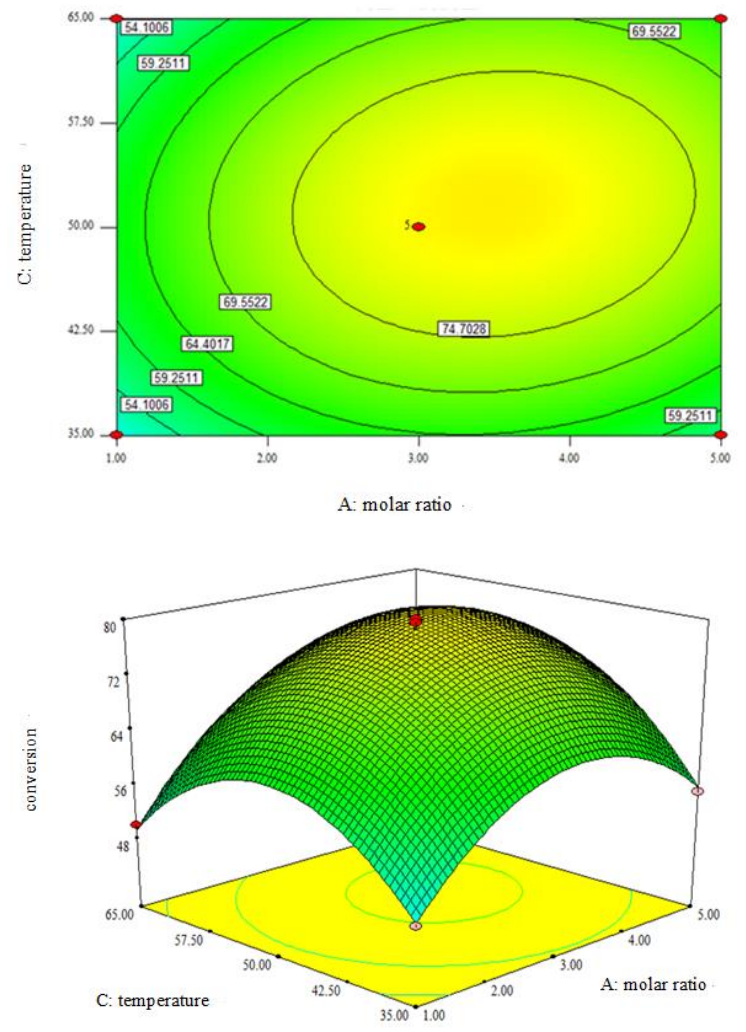

Figure 2 Contour and 3D response plots showing the mutual interaction of substrate molar ratio $[\mathrm{A}]$ and temperature $[\mathrm{C}]$ at constant time [6 h]

It was clear that the mutual interaction between the independent variables, $A$ and $B$, exhibited a strong and perfect interaction as implied by the obtained elliptical contours [Figure 3]. Based on the above values, the interaction between temperature and molar ratio was relatively significant and appeared to be strong. However, their mutual interaction was less favorable [Fvalue $=18.49]$ when compared to the interactions between time and temperature [ $F$-value $=42.25$ ] [Table 3]. It can be seen that a percentage of conversion of butyl butyrate as high as approximately $80 \%$ could be attained when the molar ratio of butyric acid:butanol was between 1:3 to 1:4 with reaction temperature ranging between 47 to $55^{\circ} \mathrm{C}$. Increased in temperature translated into increased in the production of the ester as well, probably attributable to the elevated kinetic energy within the system. This was in view of the fact that higher overall kinetic energy within the system would promote effective collisions between the enzyme and substrate molecule, resulting in the acceleration in the production rate of the ester product $[12,29,30]$. In general, increasing the reaction temperature would further increase the equilibrium 
constant [31], benefiting the reaction by improving the mass transfer between the reactant and catalyst [32], solubility of the reactants $[23,18]$ as well as reducing the viscosity of the medium [12,30]. Further increasing the temperature $\left[>55^{\circ} \mathrm{C}\right]$ did not improve the percentage conversion of the ester, possibly due to the denaturation or inactivation of the enzyme [29].

Percentage of butyl butyrate was the highest when the molar ratio of butyric acid:butanol was kept between 1:3 to 1:4. According to the thermodynamics of reactions, product formation is favored when there is a superfluous presence of the starting material in the reaction medium reaction $[16,28]$. Likewise, a higher ratio of butyric acid:butanol over the stoichiometric value utilized in this study resulted in a higher rate of ester formation, in concurrence with the previous studies on lipase-catalyzed esterification reactions performed in excess of alcohol $[16,28]$. In this investigation, the surplus alcohol helps to reduce the inherent toxicity of butyric acid towards the biocatalysts in the reaction medium that could deactivate the enzyme activity [33]. Aside from enhanced substrates mixing that may occur in the presence of surplus alcohol, the higher concentrations of the butanol too, could favorably shift the esterification reaction from hydrolysis to ester biosynthesis. This is due to the redirection of the reaction equilibrium towards product formation when the concentration of nucleophile [butanol] was raised [34]. On the other hand, reactions under conditions of low substrate molar ratio and temperature investigated in this study gave the lowest conversion of the ester [54.1\%]. At higher molar ratio [> 1:3.6], the concentration of the produced ester was found to reduce, attributable to the presence of high concentration of butanol in the reaction medium. It has been described that the excess alcohol molecules tend to accumulate onto the enzyme surface, making it difficult for acyl donor to reach the active site and hence reducing the rate of ester formation [35]. Such phenomenon observed in this study advocates a previous finding that surplus nucleophilic substrate i.e. alcohol in reaction medium may negatively affect the yield of ester by forming a non-reactive dead-end complex between an enzyme and an alcohol $[30,36]$.

\subsubsection{Effect of Time aAnd Temperature}

Figure 3 illustrates the response surface and contour plot for the effect of $B$ and $C$ as well as their mutual interaction on the Novozyme 435 catalyzed production of butyl butyrate at constant molar ratio of butyric acid:butanol [1:3]. It was observed that interactions of the two reaction variables were significant [P-value $0.0051]$. The effect of time on the yield of butyl butyrate was highly significant [F-value 1984.20] when compared with the reaction temperature [F-value 16.14], indicating that $\mathrm{C}$ played a vital role in governing the yields of the ester. Figure 3 showed a fascinating interaction between the two process variables whereby both variables had to be increased to their maximum coded values to achieve high yields of the ester. Such observation advocates on the direct proportionality between reaction time and temperature of the reaction.
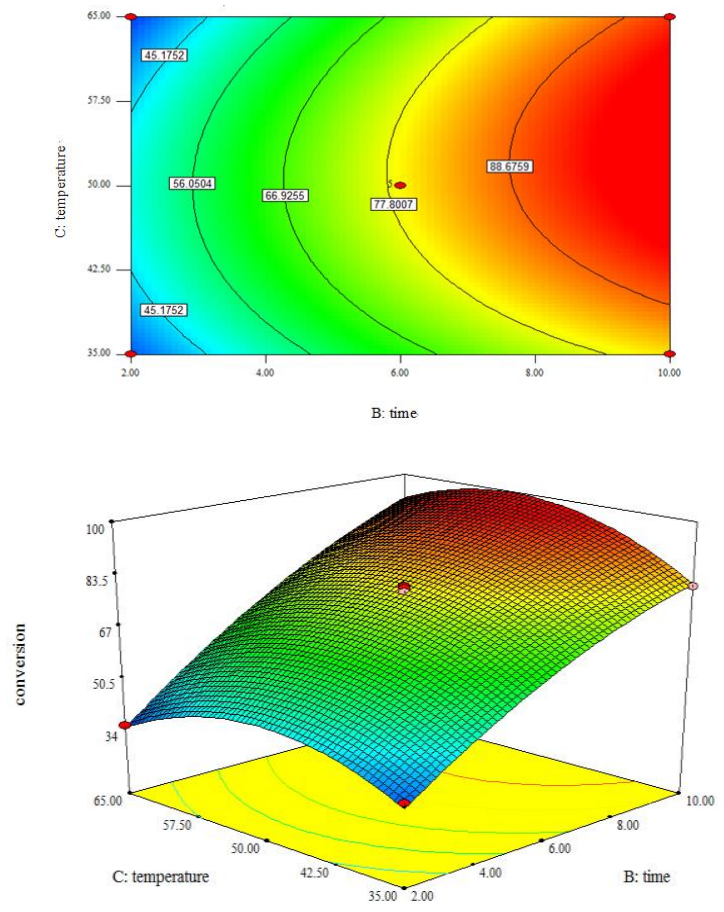

Figure 3 Contour and surface response plots showing the mutual interaction of time [B] and temperature [C] at constant molar ratio of 1:3 [butyric acid:butanol]

It was apparent from the contour and surface plots [Figure 3] that a yield as high as $90 \%$ of butyl butyrate was attainable within conditions between i] 8 to $10 \mathrm{~h}$ of reaction and ii] at any value of temperature between 50 to $57.5^{\circ} \mathrm{C}$. In contrary, when both variables were set at their lowest coded values, the percentage conversion of butyl butyrate was found to be the lowest [45.18\%]. These results imply that: [1] time was one of the key parameters that could determine the extent of the conversion of butyl butyrate and [2] such conversion may be improved by increasing both the time and temperature of reaction. Additionally, prolonging the contact time between the enzyme and substrates was seen to considerably improve the esterification production of butyl butyrate. The ascending trend in the percentage conversion of butyl butyrate, with the increase of the reaction time may be due to the longer contact time between the Novozyme 435 and substrate molecules in the reaction, increasing the propensity of effective collisions [37]. Hence, it is evident here that the reaction time has a positive effect on the esterification reaction, corroborated by the positive coefficient observed in the predictive equation [Eqn. 3].

In a nutshell, the contour plots for both reactions [effects of molar ratio versus temperature and time versus temperature] indicated that time, temperature and substrate molar ratio individually exerted strong effects on the final yields of butyl butyrate as well as in combination of all the factors [Table 3]. In view of the 
adherence to the principal of green chemistry and economic sustainability, the use of lower reaction temperature during the esterification process is often desirable, considering that it consumes less energy [12].

\subsection{Attaining Optimum Conditions and Verification of the Model}

Following the suggestion made by Salihu et al. [2014] [26], several sets of confirmation experiments were carried out within and outside of the design space based on the established optimum conditions by the $\mathrm{BBD}$. From the various experimental runs, the highest percentage yield [95\%] obtained was observed at substrate molar ratio of acid:alcohol [1:5], at $50^{\circ} \mathrm{C}$ with $10 \mathrm{~h}$ of incubation time. The experiments demonstrating the highest desirability and predicted percentage conversion values were selected for optimizing the conditions for the Novozyme 435 catalyzed esterification reaction. Two sets of optimum conditions that afforded the highest percentage conversions i.e. [i] molar ratio butyric acid:butanol 1:3.93, $9.93 \mathrm{~h}$ at $56.09^{\circ} \mathrm{C}$ and [ii] molar ratio butyric acid:butanol 1:3.35, $9.79 \mathrm{~h}$ at $53.90^{\circ} \mathrm{C}$ were selected. These optimized conditions have led to the near completion of the esterification reaction, producing $99.62 \%$ and $99.55 \%$ of the butyl butyrate, respectively.

Therefore, results of this study supported the green synthesis of butyl butyrate catalyzed by the Novozyme 435, achievable within a relatively short duration [10 h] of reaction while facilitating substantial yield of such product. Because of higher relative humidity as well as water by-product have been indicated to influence the productivity of an esterification process [30], and many such studies are limited in temperate conditions having low relative humidity, the response surface optimization of such reaction in humid countries like Malaysia appears relevant. Moreover, the employment of such approach for producing the problematic butyl butyrate remains lacking, further future studies employing larger batch studies may prove useful.

\subsection{Analysis of Butyl Butyrate}

\subsubsection{FTIR Spectroscopy: Attenuated Total Reflectance}

Confirmation of the Novozyme 435 catalyzed production of butyl butyrate is essential in proving the synthesis was successfully carried out. Here, the study used Fourier Transform Infrared-Attenuated Total Reflectance [FTIR-ATR] analysis for initial confirmation of the produced ester. The analyses were conducted on samples of the reaction mixtures at both $0 \mathrm{~h}$ and $10 \mathrm{~h}$ [Figure 4a-b], respectively. Several significant peaks that corresponded to the different wavelengths were observed. A broad peak observable between 3400$2500 \mathrm{~cm}^{-1}$ can be assigned to the $\mathrm{O}-\mathrm{H}$ stretching [Figure 4a] of butyric acid, consistent with the reported hydroxyl functional group from the dimerization of carboxylic acids [38]. In contrast, the typically broad peak of the $\mathrm{O}-\mathrm{H}$ stretching for butyric acid was found to reduce in the samples of the $10 \mathrm{~h}$ reaction mixture [Figure 4b], suggesting the marked reduction of butyric acid in producing butyl butyrate. The $\mathrm{O}-\mathrm{H}$ stretching [3382.93 $\mathrm{cm}^{-1}$ ] [Figure 4b] may be attributable to the remaining excess butanol used for the esterification production of butyl butyrate.

It has been indicated that the $\mathrm{C}=\mathrm{O}$ of carboxylic acid and saturated aliphatic esters are represented within the regions of $1760-1690 \mathrm{~cm}^{-1}$ and $1750-1735 \mathrm{~cm}^{-}$ 1, respectively [38]. Therefore, a strong peak observed at $1710 \mathrm{~cm}^{-1}$ [Figure 5a] can be attributed to the presence of $\mathrm{C}=\mathrm{O}$ of carboxylic acid within the mixture, fell well within the reported region. However, the $\mathrm{C}=\mathrm{O}$ peak had shifted to a slightly higher region of the spectrum [1736.58 $\mathrm{cm}^{-1}$ ] [Figure 4b] after $10 \mathrm{~h}$ of incubation time for the mixture, indicating that such peak may be due to the formation of aliphatic saturated ester [Wade Jr, 2003]. In addition, a peak that corresponded with the presence of carboxylic acid [1070.88 $\mathrm{cm}^{-1}$ ] [Figure 4a] was observed at $0 \mathrm{~h}$ of reaction time, while during the $10 \mathrm{~h}$ reaction time the C-O stretch had to shifted to a higher wavenumber indicating the formation of aliphatic ester $[1181.44 \mathrm{~cm}$ 1] [Figure 5b]. This finding was in concurrence with that reported by Stuart [2005] [39] and Bruno et al., [2008] [40]. 
a]

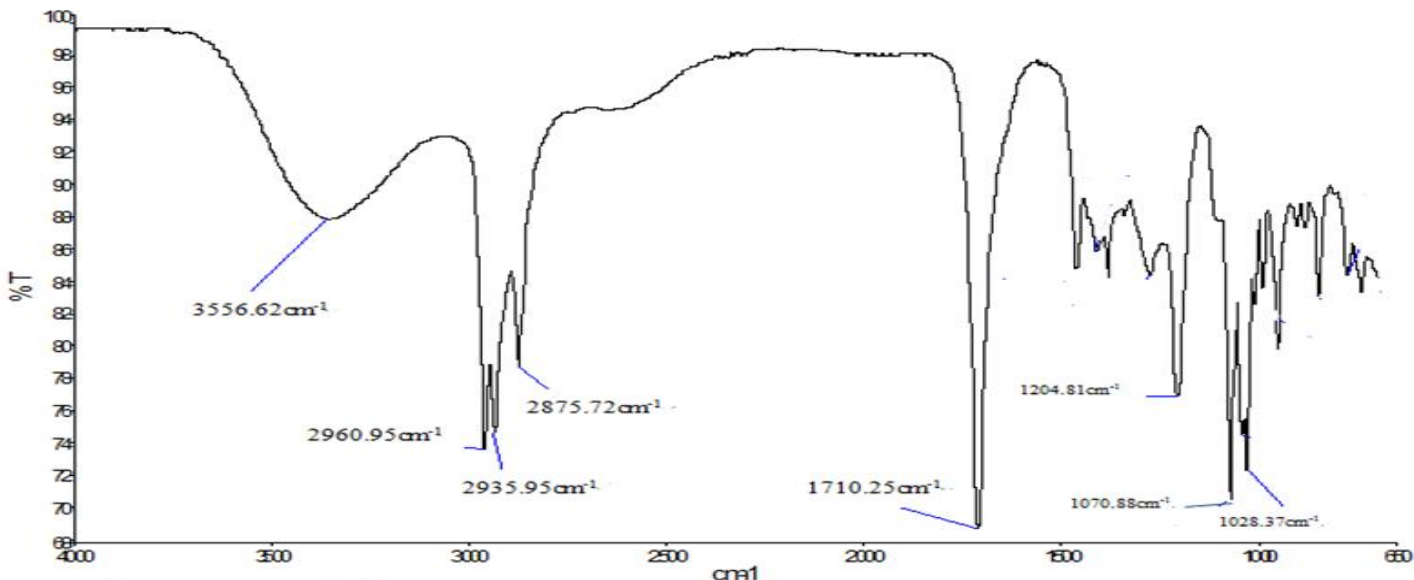

b]

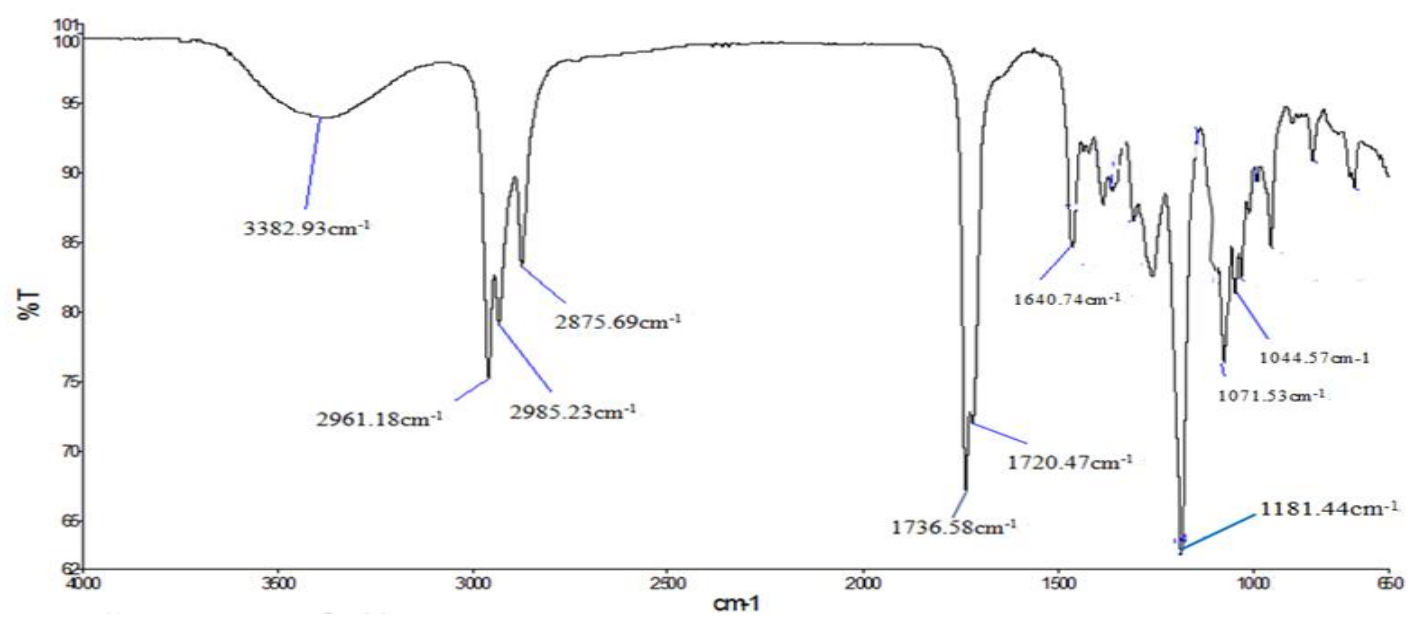

Figure 4 FTIR spectra of the reaction mixtures for the Novozyme 435 catalyzed solvent-free esterification of butyl butyrate at a) $0 \mathrm{~h}$ and b) $10 \mathrm{~h}$

\subsubsection{Gas Chromatography}

The production of butyl butyrate following esterification of butyric and butanol catalyzed by the Novozyme 435 was confirmed with the use of gas chromatography [Figure 5a-b]. The chromatogram for the samples analyzed at $0 \mathrm{~h}$ indicated that hexane [solvent], butanol and butyric acid eluted at 1.758, 3.077 and 5.244 min, respectively, with no indication on the presence of butyl butyrate. Hence, the possibility of autoesterification can be ruled out. Expectedly, the presence of butyl butyrate [5.300 $\mathrm{min}$ ] as well as hexane [1.770 min] and limited amount of butanol [2.837 min] was detected in the chromatogram of the $10 \mathrm{~h}$ reaction sample, while butyric acid was completely undetectable [Figure 5b]. Such findings indicated the successful conversion of butyric acid [limiting reagent] and butanol into butyl butyrate catalyzed by the Novozyme 435 in a solvent-less system. a)

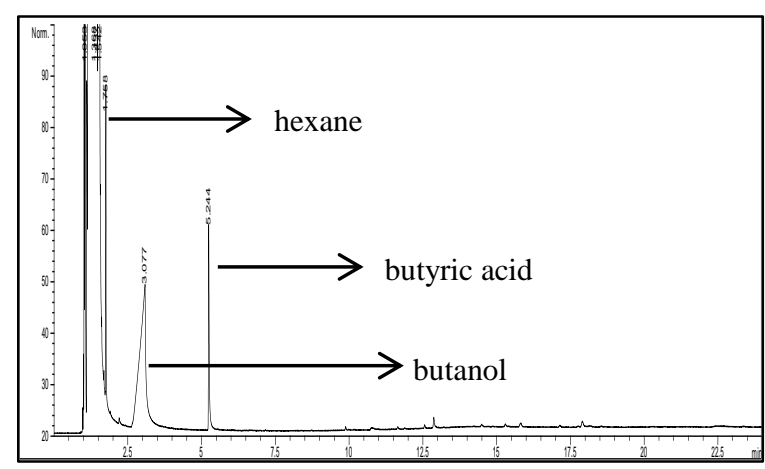

b)

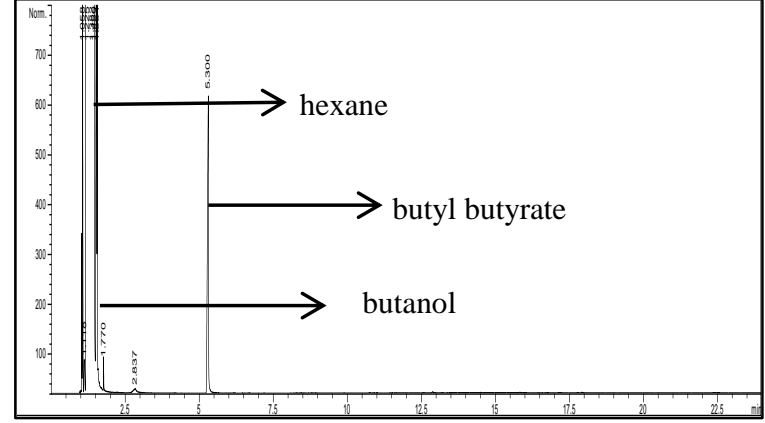

Figure $\mathbf{5}$ Chromatogram of the esterification mixture at a) $0 \mathrm{~h}$ and b) $10 \mathrm{~h}$ catalyzed by Novozyme 435 


\subsection{CONCLUSION}

This present study successfully evaluated the optimized conditions suggested by the response surface methodological technique i.e. BBD utilizing Novozyme 435 as biocatalysts for producing butyl butyrate via a solvent-less reaction system. Considerably high percentages of conversion to butyl butyrate [> 99\%] were observed following the use of the 2 sets of optimum conditions prescribed by the Design Expert 7.1.6 software detailed below. The percentages of conversion being $99.62 \%$ and $99.55 \%$ when the reactions were performed at [i] molar ratio of butyric acid:butanol $1: 3.93,9.93 \mathrm{~h}$ at $56.09^{\circ} \mathrm{C}$ and [ii] molar ratio butyric acid:butanol 1:3.35, $9.79 \mathrm{~h}$ at $53.90^{\circ} \mathrm{C}$, respectively. Results of the FTIR (Figure 4) and GC (Figure 5) analyses further confirmed such finding, demonstrating the presence of such high quantities of butyl butyrate with the complete absence of butyric acid [limiting reagent] and limited amount of the excess butanol. Therefore, while this present study concurs that the application of Novozyme 435 in the solvent-less esterification production of butyl butyrate as useful; the optimized conditions revealed by the BBD design may prove beneficial for yielding higher conversion of the ester, an important aspect in the mass production of such material. Further studies utilizing GC-MS for positively confirming the identity of the produced ester may prove useful.

\section{Acknowledgement}

This work was supported by the Research University Grant [grant number Q.J130000.2526.13H09, 2016] from Universiti Teknologi Malaysia, Johor and the Fundamental Research Grant Scheme [grant number R.J130000.7826.4F649,2016]. We would also like to acknowledge valuable help and suggestions provided by our colleagues.

\section{References}

[1] Ju, I. B., Lim, H-W., Jeon, W., Suh, D. J., Park M-J. \& Suh, Y-W. 2011. Kinetic Study of Catalytic Esterification of Butyric Acid and n-butanol over Dowex 50W x 8-400. Chemical Engineering. 168: 293-302.

[2] Mohamad, N. R., Buang, N. A., Mahat, N. A., Huyop, F., Jamalis, J., Aboul-Enein, H. Y. \& Wahab, R. A. 2015a. Simple Adsorption of Candida rugosa Lipase Onto Multi-walled Carbon Nanotubes for an Economical and Sustainable Production of the Flavor Ester Geranyl Propionate. Journal of Industrial and Engineering Chemistry. 32: 99-108.

[3] Mohamad, N. R., Mahat, N. A., Lok, Y. Y., Huyop, F., AboulEnein, H.Y. \& Wahab, R. A. 2015b. A Facile Enzymatic Synthesis of Geranyl Propionate by Physically Adsorbed Candida rugosa Lipase onto Multi-walled Carbon Nanotubes. Enzyme and Microbial Technology 72: 49-55.

[4] Marzuki, N. H. C., Mahat, N. A., Buang, N. A., Huyop, F. \& Wahab, R. A. 2015a. Candida rugosa Lipase Immobilized Onto Acid-functionalized Multi Walled Carbon Nanotubes for Sustainable Production of Methyl Oleate. Applied Biochemistry and Biotechnology. 177(4): 967-984.
[5] Chowdhury, A., Mitra, D. \& Biswas, D. 2014. Synthesis of Biolubricant Components from Wastes of Cooking Oil Using Biocatalytic Route. Env Prog Sust Ener. 33(3): 933-940.

[6] Rajendran, A., Palaisamy, A. \& Thangavelu, V. 2009. Lipase Catalysed Ester Synthesis for Food Processing Industries. Brazilian Archive Biology and Technology. 52: 207-219.

[7] Skoronski, E., Padoin, N., Soares, C. \& Furigo Jr. A. 2014. Stability of Immobillized Rhizomucor miehei Lipase for the Synthesis of Pentyl Octanoate in a Continuous Packed Bed Bioreactor. Brazilian Journal of Chemical Engineering. 31 (3): 633-641.

[8] Ferraz, L.I.R., Possebom, G., Valandro, A., Luiz, E., Cansian, R., Paroul, N., de Oliveira, D. \& Treichel, H. 2015. Application of Home-made Lipase in the Production of Geranyl Propionate by Esterification of Geraniol and Propionic Acid in SolventFree System. Biocatal Agri Biotechnol. 4(1): 44-48.

[9] Talebi, M., Vaezifar, S., Jafary, F., Fazilati, F. \& Motamedi, S. 2016. Stability Improvement of Immobilized A-Amylase Using Nano Pore Zeolite. Iranian Journal of Biotechnology. 14(1): e1261.

[10] Zou, B., Hu, Y. \& YU, D. 2010. Immobilization of Porcine Pancreatic Lipase onto Ionic Liquid Modified Mesoporous Silica SBA-15. Biochemical Engineering Journal. 53(1): 150153.

[11] Kharrat. N., Ali, Y. B., Marzouk, S., Gargouri, Y-T. \& KarraChâabouni, M. 2011. Immobilization of Rhizopus oryzae Lipase on Silica Aerogels by Adsorption: Comparison with the Free Enzyme. Process Biochemistry. 46(5):1083-1089.

[12] Wahab, R., Abdul Rahman, M. B., Chaibakhsh, N., Leow, T. C., Basri, M., Abdul Rahman, R. N. Z. Salleh, A. B. 2014. Enzymatic Production of a Solvent-free Menthyl Butyrate via Response Surface Methodology Catalyzed by a Novel Thermostable Lipase from Geobacillus zalihae. Biotechnology and Biotechnological Equipment. 28(6): 13102818.

[13] Marzuki, N. H. C., Mahat, N. A., Aboul-Enein H., Huyop F. \& Wahab, R. A. 2015b. Modeling and Optimization of Candida rugosa Nanobioconjugates Catalysed Synthesis of Methyl Oleate by Response Surface Methodology. Biotechnology and Biotechnological Equipment. 29(6): 1113-1127.

[14] Wu, W-J. \& Ahn, B-Y. 2014. Statistical Optimization of Ultraviolet Irradiate Conditions for Vitamin D2 Synthesis in Oyster Mushrooms [Pleurotus ostreatus] using Response Surface Methodology. PLoSOne 9[4]: e95359. doi:10.1371/journal.pone.0095359.

[15] Bas, D. \& Boyacı. I. H. 2007. Modelling and Optimization I: Usability of Response Surface Methodology. Journal of Food and Engineering. 78: 836-845.

[16] Martins, A. B., Graebin, N. G., Lorenzoni, A. S. G., FernandezLafuente, R., Ayub, M. A. Z. \& Rodrigues, R. C. 2011. Rapid and High Yields of Synthesis of Butyl Acetate Catalyzed by Novozym 435: Reaction Optimization by Response Surface Methodology. Process Biochemistry. 46(12): 2311-2316.

[17] Mohamad, N. R., Mahat, N. A., Huyop, F., Aboul-Enein, H. Y. \& Wahab, R. A. 2015c. Response Surface Methodological Approach for Optimizing Production of Geranyl Propionate Catalysed by Carbon Nanotubes Nanobioconjugates. Biotechnology and Biotechnological Equipment. 29(4): 732739.

[18] Raghavendra, T., Panchal, N., Divecha, J., Shah, A. \& Madamwar, D. 2014. Biocatalytic Synthesis of Flavor Ester "pentyl valerate" using Candida rugosa Lipase Immobilized in Microemulsion based Organogels: Effect of Parameters and Reusability. BioMed Research International. 353845; doi:10.1155/2014/353845.

[19] Low, C. T., Mohamad, R., Tan, C. P., Long, K., Ismail, R., Lo, S. K. \& Lai, O. M. 2007. Lipase-catalyzed Production of MediumChain Triacylglycerols from Palm Kernel Oil Distillate: Optimization Using Response Surface Methodology. European Journal of Lipid Science and Technology. 109 (2): 107-119.

[20] Gunawan, E. R., Basri, M., Abd Rahman, M. B., Salleh, A. B. \& Abd Rahman, R. N. Z. 2005. Study on Response Surface Methodology [RSM] of Lipase-catalyzed Synthesis of Palm- 
based Wax Ester. Enzyme and Microbial Technology. 37: 739744.

[21] Deepika, K. V., Kalam, S., Sridhar, P. R., Podile, A. R. \& Bramchari, P. V. 2016. Optimization of Rhamnolipid Biosurfactant Production by Mangrove Sediment Bacterium Pseudomonas aeruginosa KVD-HR42 Using Response Surface Methodology. Biocatalysis and Agricultural Biotechnology. 5: 38-47.

[22] Liu, W., Yin, P., Liu, X. \& Qu, R. 2014. Design of an Effective Bifunctional Catalyst Organotriphosphonic Acidfunctionalized Ferric Alginate [ATMP-FA] and Optimization by Box-Behnken Model for Biodiesel Esterification Synthesis of Oleic Acid Over ATMP-FA. Bioresource Technology. 173: 266271.

[23] Abdul Rahman, M. B., Chaibakhsh, N., Basri, M., Rahman, R. N. Z. A. \& Salleh, A. B. 2008. Modelling and Optimization of Lipase-catalyzed Synthesis of Dilauryl Adipate Ester by Response Surface Methodology. Journal of Chemical Technology and Biotechnology. 83: 1534-1540.

[24] Pujari, V. \& Chandra, T. 2000. Statistical Optimization of Medium Components for Enhanced Riboflavin Production by a UV Mutant of Eremothycium ashbyii. Process Biochemistry. 36(1): 31-37.

[25] Nuthalapati, V., Ramalingam, C., Dasgupta, N., Ranjan, S., Varghese, L. R. \& Mandal, S. K. 2014. Optimization of Growth Medium Using a Statistical Approach for the Production of Plant Gallic Acid from a Newly Isolated Aspergillus tubingenesis NJA-1. Journal of Pure and Applied Microbiology. 8: 3313-3324.

[26] Salihu, A., Alam, M. Z., Karim, M. I. A. \& Salleh, H. M. 2014. Esterification for Butyl Butyrate Formation using Candida cylindracea Lipase Produced from Palm Oil Mill Effluent Supplemented Medium. Arabian Journal of Chemistry. 7(6): 1159-1165.

[27] Chaibakhsh, N., Rahman, M. B. A., Abd-Aziz, S., Basri, M., Salleh, A. B. \& Rahman, R. N. Z. R. A. 2009. Optimized Lipasecatalyzed Synthesis of Adipate Ester in a Solvent-free System. Journal of Industrial Microbiology and Biotechnology. 36(9): $1149-1155$

[28] Dwivedi, G. \& Sharma, M.P. 2015. Application of BoxBehnken Design in Optimization of Biodiesel Yield from Pongamia Oil and Its Stability Analysis. Fuel. 145: 256-262.

[29] Abdul Rahman, M. B., Chaibakhsh, N. \& Basri, M. 2011. Effect of Alcohol Structure on the Optimum Condition for Novozyme 435-catalyzed Synthesis of Adipate Esters. Biotechnol Research International. doi:10.4061/2011/162987.
[30] Isah, A. A., Mahat, N. A., Jamalis, J., Attan. N., Zakaria, I.I., Huyop, F. \& Wahab. R. A. 2016. Synthesis of Geranyl Propionate in a Solvent-free Medium using Rhizomucor miehei Lipase Covalently Immobilized on Chitosangraphene Oxide Beads. Preparative Biochemistry and Biotechnology. DOI:10.1080/10826068.2016.1201681.

[31] Verissimo, L. A. A., Soares, W. C. L., Mol, P. C. G., Minim, V. P. R., da Silva, M. C. H. \&Minim, L. A. 2015. Optimization of Flavor Ester Synthesis Catalysed by Aspergillus niger Lipase. African Journal of Microbial Research. 9(13): 922-928.

[32] Paroul, N., Grzegozeski, L.P., Ciaradia, V., Treichel, H. Cansian, R. L., de Oliveira. V. \& de Olivera, D. 2010. Production of Geranyl Propionate by Enzymatic Esterification of Geraniol and Propionic in Solvent Free System. Journal of Chemical Technology and Biotechnology. 85(12): 1636-1641.

[33] Couto, R., Vidinha, P., Peres, C., Ribeiro, A. S., Ferreira, O. Oliveira, M. V. \& Barreiros, S. 2011 . Geranyl Acetate Synthesis in a Packed-bed Reactor Catalyzed by Novozyme in Supercritical Carbon Dioxide and in Supercritical Ethane. Industrial Engineering Chemistry Research. 50(4): 1938-1946.

[34] Manan, F. M. A., Rahman, I. N. A., Marzuki, N. H. C., Mahat, N. A., Huyop, F. \& Wahab, R. A. 2016. Statistical Modelling of Eugenol Benzoate Synthesis using Rhizomucor miehei Lipase Reinforced Nanobioconjugates. Process Biochemistry. 51 (2): 249-262.

[35] Soyer, A., Bayraktar, E. \& Mehmetoglu, Ü. 2010. Optimization of Lipase-catalyzed Enantioselective Production of 1-phenyl 1-propanol using Response Surface Methodology. Preparative Biochemistry Biotechnology. 40(4): 389-404.

[36] Yadav, G. D. \& Lathi, P. S. 2004. Synthesis of Citronellol Laurate in Organic Media Catalyzed by Immobilized Lipases: Kinetic Studies. Journal of Molecular Catalysis B: Enzymatic. 27: 113119.

[37] Chen, X.; Yin, P.; Du, W.; Liu, D. 2008. Effect of Several Factors on Soluble Lipase-mediated Biodiesel Preparation in the Biphasic Aqueous-oil Systems. World J Microbiol Biotechnol. 24: 2097-2102

[38] Wade Jr, L. G. 2013. Organic Chemistry. 8th Edition. Pearson Publishing, Boston, MA.

[39] Stuart, B. H., George, W. O., Mclntyre, P. S. 1996. Modern Infrared Spectroscopy. John Wiley and Sons, Inc., Chichester. 200.

[40] Bruno, L. M., de Lima Filho, J. L. \& de Castro, H. F. 2008. Comparative Performance of Microbial Lipases Immobilized on Magnetic Polysiloxane Polyvinyl Alcohol Particles. Brazilian Archive of Biololgy and Technology. doi.org/10.1590/S151689132008000500003. 